\title{
Atopik Dermatitli Hastalarda Malassezia Yükünün Moleküler Yöntemler ile Gösterilmesi
}

\section{Molecular Analysis of Malassezia Load in Patients with Atopic Dermatitis}

\section{Meltem Önder, Ayșe Kalkancı* Canan Kevlekçi, Mehmet Ali Gürer, Takashi Sugita**}

Gazi Üniversitesi Tıp Fakültesi, Deri ve Zührevi Hastalıklar Anabilim Dalı ve *Tıbbi Mikrobiyoloji Anabilim Dalı, Ankara, Türkiye

**Meiji Eczacılık Üniversitesi, Mikrobiyoloji Bölümü, Kiyose, Tokyo, Japonya

Özet

Amaç: Atopik dermatit (AD) etyolojisinde ve hastalık alevlenmesinde Malassezia cinsi mayaların rolü olduğu bildirilmektedir. Bu çalıșmada atopik dermatitli hastalarda derideki Malassezia yükünü göstermek için geliștirilen, kültürden bağımsız bir moleküler yöntem sunulmaktadır.

Gereç ve Yöntem: Üç farklı (hafif, orta, ciddi) klinik evredeki atopik dermatitli hastaların Malassezia kolonizasyon oranları, kantitatif gerçek zamanlı polimeraz zincir reaksiyonu (kGZ-PZR) kullanılarak incelenmiștir. Kırk-yedi (47) atopik dermatitli hasta, ve 75 erișkin sağlıklı birey çalıșmaya dahil edilmiștir. Hastaların ve sağlıklı grubun yüz ve boyunda lezyon olan ve olmayan bölgelerinden deri kepek örnekleri flastere yapıștırılarak alınmıștır. Flastere yapıșan kepek örneklerinden fungal DNA izole edilmiș ve Malassezia DNA'sının gösterilmesi için GZ-PZR ișlemine alınmıștır.

Bulgular: Olgu sayısı 47 hasta, 75 sağlıklı birey olmak üzere (62 kadın, 60 erkek) 122'dir. Kantitatif analizlere göre Malassezia kolonizasyonu $A D$ ve sağlıklı grup arasında farklı bulunmamıștır. Ciddi $A D^{\prime} i$ olan grup ile orta veya hafif $A D^{\prime} i$ olan gruplar arasında Malassezia yükü açısından bir fark gösterilememiștir $(p=0,409)$.

Sonuç: Çalıșmamızın bașında, daha önceki Japon çalıșmalarında gösterilen Malassezia yükü ile AD arasındaki ilișkiyi bulmayı amaçlamamıza rağmen, çalıșma sonunda Türk AD grubunda sağlıklı gruptan farklı bir fungal yük bulunmamıștır. Ancak, deri hastaIıklarının patogenezinde mikroorganizmaların rolü konusunda çalıșmalara devam edilmelidir. (Türkderm 2011; 45: 206-9)

Anahtar Kelimeler: Malassezia, atopik dermatit, klinik evre, gerçek zamanlı PZR, kantitasyon

\section{Summary}

Background and Design: Atopic dermatitis (AD) is a multifactorial disease in which Malassezia species are also considered to be one of the factors that exacerbate AD. We have developed a culture-independent method for analyzing cutaneus Malassezia load in patients with atopic dermatitis.

Materials and Methods: The diversity of Malassezia flora in Turkish patients with atopic dermatitis of three different clinical severities (mild, moderate, and severe) were compared using quantitative real time polymerase chain reaction (qRT-PCR) method. Fourthy-seven individuals with $A D$ and seventy-five adult healthy individuals were sampled in this study. Skin samples were collected by stripping the face and neck of each subject. Fungal DNA extraction was performed and the detection of Malassezia DNA by real-time PCR was conducted.

Results: Total number of patients was 122, including 47 patients and 72 healthy controls (62 female, 60 male). Quantitative analysis of Malassezia colonization in the $A D$ group and healthy control group was not significantly different between the $A D$ and healthy control groups. In patients with severe AD, Malassezia colonization was not different that in mild and moderate $A D$ patients and healthy individuals, and the differences among them were not statisticaly significant $(\mathrm{p}=0.409)$.

Conclusion: We could not find any difference in our patient group in terms of Malassezia colonization rate, although we had hypothesized. We could not show a fungal factor for the severity of the disease in AD patients. Japanese authors showed such a kind of relationship in the past. Besides, skin diseases should be evaluated carefully for the presence of microorganisms as an important factor of pathogenesis of the disease. (Turkderm 2011; 45: 206-9)

Key Words: Malassezia, atopic dermatitis, clinical severity, real-time PCR, quantitation

Yazışma Adresi/Address for Correspondence: Dr. Ayșe Kalkancı, Gazi Üniversitesi Tıp Fakültesi, Tıbbi Mikrobiyoloji Anabilim Dalı, Ankara, Türkiye E-posta: aysekalkanci@email.com Geliş Tarihi/Received: 02.02.2011 Kabul Tarihi/Accepted: 14.04.2011

Türkderm-Deri Hastalıkları ve Frengi Arșivi Dergisi, Galenos Yayınevi tarafından basılmıștır.

Turkderm-Archives of the Turkish Dermatology and Venerology, published by Galenos Publishing. 


\section{Giriş}

Atopik dermatit (AD) sık görülen, kronik inflamatuvar bir hastalıktır. Hastalık genel olarak yaşamın ilk iki yılında başlar ve her üç olgudan ikisi erişkin dönemde de devam eder. AD genetik ve çevresel faktörlerin de etkili olduğu, çok faktörlü bir hastalıktır. AD'i olan hastalar bazı bakteriyel, fungal ve viral hastalıklara daha duyarlıdır. Yaşamın erken dönemlerinde mikrobiyal antijenler ile yeterince karşılaşmamış bireylerde hastalık riski artmaktadır. AD’li bireylerde antimikrobiyal peptidlerin azalması, yardımcı T hücrelerin Th2 tipindeki sitokinleri (IL-4, IL10 gibi) daha baskın olarak salgılamaları ile açıklanabilir. Deri yüzeyindeki bağışıklık sisteminin bozulması özellikle Staphylococcus aureus and Malassezia kolonizasyonunun artmasına neden olmaktadır., ${ }^{1,3}$

Malassezia (eskiden Pityrosporum orbiculare/ovale olarak bilinmekteydi) derinin normal florasının bir elemanı olup, aynı zamanda "pityriasis versicolor (PV)", Malassezia folliküliti, seboreik dermatit, kepeklenme ve $A D$ gibi bazı hastalıkların da patogenezinde etkilidir.,4

Bu çalışmada, AD'li hastaların derisinde Malassezia yükünü araştırmak için geliştirdiğimiz, kültürden bağımsız bir moleküler yöntem sunulmaktadır. Üç farklı klinik tablo gösteren AD hasta grubunda, (ciddi, orta ve hafif seyirli hastalık) Malassezia yükü ile bir ilişki olup olmadığı kantitatif gerçek zamanlı polimeraz zincir reaksiyonu (kGZPZR) yöntemi ile incelenmiştir.

\section{Gereç ve Yöntem}

\section{Hastalar}

Erişkin yaş grubundan AD'li 47 hasta çalışmaya dahil edilmiştir. Kontrol grubu olarak, yaş grubu benzer 75 sağlıklı bireyden deri örnekleri alınmıştır. Hastaların yaş ortalaması 36ะ15 olarak hesaplanmıştır. Toplam 122 hastanın 62'si kadın ve 60'ı erkektir. Bütün hastalar Gazi Üniversitesi Tıp Fakültesi, Deri ve Zührevi Hastalıklar Anabilim Dalı polikliniklerinde takip edilmiş ve Hanifin ve Rajka kriterlerine görse $A D$ tanısı almıştır. ${ }^{5}$ Bütün çalışma Helsinki Bildirisi'ne uygun etik kurul onayı altında devam ettirilmiştir. Hastaların tamamından "bilgilendirilmiş gönüllü olur formu" alınmıştır. Deri örnekleri yurtdışına gönderildiği için ayrıca bu konuda da Sağlık bakanlığından izin alınmıştır.

\section{Örnek toplanması}

Örnek alımı için "OpSiteTM (3x7 cm; Smith and Nephew Medical, Hull, UK)" hastanın yüz ve boyundaki lezyonlu veya lezyonsuz deri bölgesine yapıştırılmış ve çekilmiştir. Deri örneklerini içeren "OpSite" $-20^{\circ} C^{\prime}$ de saklanmıştır.

\section{DNA eldesi ve çoğaltılması}

Toplanan "OpSite" yüzeyleri Gazi Üniversitesi, Mikrobiyoloji Bölümü'ne gönderilmiştir. Örnekler parçalama tamponu [(100 mmol/L) Tris- $\mathrm{HCl}(\mathrm{pH} 8,0,30 \mathrm{mmol} / \mathrm{L})$ ethylenediaminetetraacetic acid (EDTA) $\mathrm{pH} 8,0, \% 0,5$ sodium dodecyl sulphate (SDS)] içinde $100^{\circ} \mathrm{C}^{\prime}$ de $15 \mathrm{dk}$ bekletilmiştir. Karışımdan DNA eldesi için fenol-kloroform-izoamil alkol (25:24:1,wv) ve kloroform-izoamil alkol (24:1,wv), kullanılmıştır. Elde edilen DNA etanol-sodyum asetat-Ethatinmate (Nippon Gene, Toyama, Japan) ile çöktürülmüştür. DNA çökeleği $30 \mu \mathrm{L}$ TE tamponu [(10 mmol/L) Tris- $\mathrm{HCl}(\mathrm{pH} 8,0,1 \mathrm{mmol} / \mathrm{L})$ EDTA $(\mathrm{pH} \mathrm{8,0)]} \mathrm{ile} \mathrm{tekrar}$ sulandırılmış ve- $20^{\circ} \mathrm{C}^{\prime}$ de saklanmıştır.,

\section{Malassezia'nın kantitatif analizi}

Malassezia DNA'sının GZ-PZR ile kantitatif olarak çoğaltılması için daha önceden belirlenmiş iki çift primer seti ve bir adet işaretli prob kullanılmıştır. (Mala-F- CTA AAT ATC GGG GAG AGA CCG A, Mala-RGTA CTT TTA ACT CTC TTT CCA CCG TGC TT, Mala prob FAM-TTC ATC TTT CCC TCA CGG TAC-MGB) kullanılmıştır., Cinse özgül primerler ribozomal RNA gen bölgesinin internal transcribed spacer 1 (ITS1) ve IGS 1 bölgelerini çoğaltmak üzere tasarlanmıştır. Fungal DNA TaqMan prob kullanılarak gerçek zamanlı PZR cihazında kantitatif olarak çoğaltılmıştır. Çoğaltma ve gösterme için ABI PRISM 7500 sistemi kullanılmıştır (Applied Biosystems, Foster City, CA).

\section{İstatistiksel analiz}

Malassezia DNA kopya sayıları ile gruplar arasında karşılaştırma yapabilmek için Fischer kesin testi kullanılmıştır. İki grup arasında $p<0,05$ bulunduğunda fark istatistiksel olarak anlamlı kabul edilmiştir.

\section{Bulgular}

Çalışma kapsamında 47 AD hastası ile 75 sağlıklı kontrolden alınan deri örneklerinde Malassezia yükü araştırılmıştır. AD grubunda 9 hasta hafif, 26 hasta orta, 12 hasta da ciddi AD olarak sınıflandırımıştır. Malassezia yükünün kantitatif analizi için alt sınır 10 kopya/ml olarak belirlenmiştir. Yükü bilinmeyen örneklerin kopya sayıları plazmid kopya sayıları esas alınarak hesaplanmıştır.

Sağlıklı kontrol grubu ile AD grubu arasında Malassezia yükü açısından bir fark gösterilmemiştir ( $t=0,962$, 2-tailed=0,341). Ciddi AD'li hasta grubu ile orta veya hafif seyirli grup arasında da Malassezia yükü açısından bir fark gösterilememiştir $(p=0,409)$. Tablo'da hastalardan elde edilen bütün fungal yükler listelenmiştir.

\section{Tartışma}

Malassezia cinsi mayalar normal deri florasının bir üyesi olup, aynı zamanda birçok deri hastalığının patogenezinde yer almaktadırlar. ${ }^{3,4}$ Deri yüzeyindeki Malassezia kolonizasyonunun gösterilmesi için çeşit-

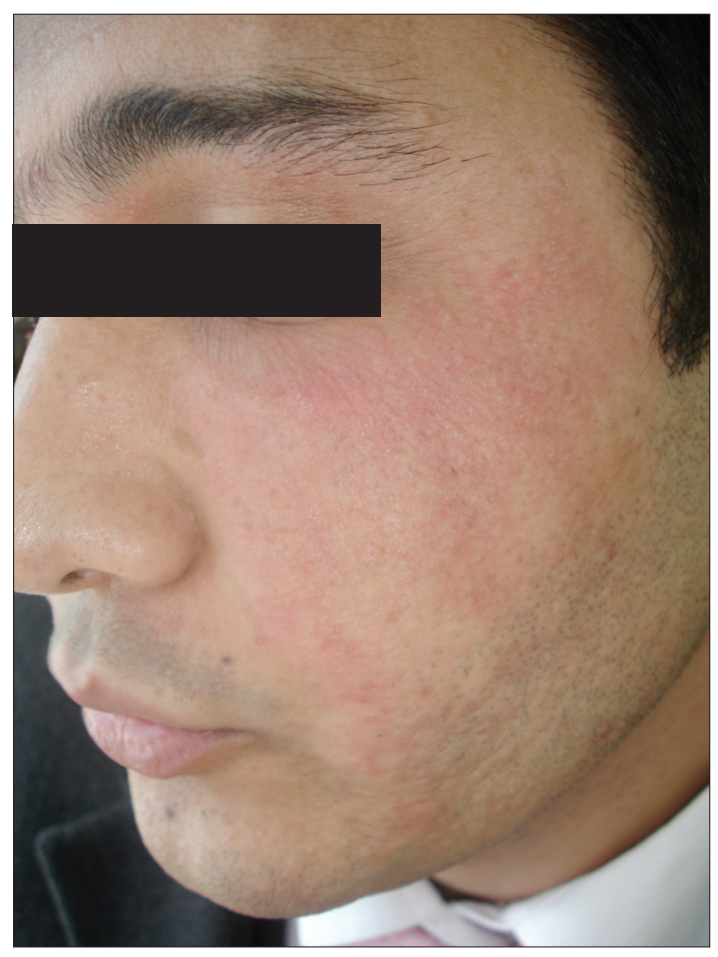

Resim 1. Atopik dermatitli bir hastanın yüz lezyonları 


\section{Tablo : Atopik dermatitli 47 olgunun Malassezia yükleri}

\begin{tabular}{|c|c|c|c|}
\hline & Anatomik bölge & Klinik & $\begin{array}{c}\text { Malassezia yükü } \\
\text { (DNA kopya sayısı) }\end{array}$ \\
\hline 1 & Lezyon/yüz & Orta & 467438 \\
\hline 2 & Lezyon/boyun & Orta & 507053 \\
\hline 3 & Lezyon yok/yüz & Orta & 512858 \\
\hline 4 & Lezyon/yüz & Orta & 76451 \\
\hline 5 & Lezyon/boyun & Orta & 320922 \\
\hline 6 & Lezyon/yüz & Orta & 124386 \\
\hline 7 & Lezyon/boyun & Orta & 244618 \\
\hline 8 & Lezyon yok/boyun & Orta & 87123 \\
\hline 9 & Lezyon/yüz & Hafif & 220427 \\
\hline 10 & Lezyon/boyun & Hafif & 1100000 \\
\hline 11 & Lezyon yok/boyun & Hafif & 65475 \\
\hline 12 & Lezyon/yüz & Orta & 3380000 \\
\hline 13 & Lezyon/boyun & Orta & 2610000 \\
\hline 14 & Lezyon yok/boyun & Orta & 265384 \\
\hline 15 & Lezyon/yüz & Ciddi & 285142 \\
\hline 16 & Lezyon/boyun & Ciddi & 512323 \\
\hline 17 & Lezyon yok/yüz & Ciddi & 83203 \\
\hline 18 & Lezyon/yüz & Orta & 750303 \\
\hline 19 & Lezyon/yüz & Orta & 1150000 \\
\hline 20 & Lezyon yok/boyun & Orta & 94125 \\
\hline 21 & Lezyon/yüz & Hafif & 27800000 \\
\hline 22 & Lezyon/boyun & Hafif & 3860000 \\
\hline 23 & Lezyon yok/boyun & Hafif & 165218 \\
\hline 24 & Lezyon/yüz & Ciddi & 50007 \\
\hline 25 & Lezyon/boyun & Ciddi & 52667 \\
\hline 26 & Lezyon yok/yüz & Ciddi & 68572 \\
\hline 27 & Lezyon/yüz & Orta & 3090000 \\
\hline 28 & Lezyon/boyun & Orta & 1910000 \\
\hline 29 & Lezyon yok/boyun & Orta & 222873 \\
\hline 30 & Lezyon/yüz & Orta & 616224 \\
\hline 31 & Lezyon/boyun & Orta & 586765 \\
\hline 32 & Lezyon yok/boyun & Orta & 818675 \\
\hline 33 & Lezyon/yüz & Orta & 175181 \\
\hline 34 & Lezyon/boyun & Orta & 252335 \\
\hline 35 & Lezyon yok/yüz & Orta & 78943 \\
\hline 36 & Lezyon/yüz & Ciddi & 3050000 \\
\hline 37 & Lezyon/boyun & Ciddi & 198050 \\
\hline 38 & Lezyon yok/boyun & Ciddi & 149718 \\
\hline 39 & Lezyon/yüz & Ciddi & 1060000 \\
\hline 40 & Lezyon/boyun & Ciddi & 341440 \\
\hline 41 & Lezyon yok/boyun & Ciddi & 146774 \\
\hline 42 & Lezyon/yüz & Hafif & 264216 \\
\hline 43 & Lezyon/boyun & Hafif & 180413 \\
\hline 44 & Lezyon yok/yüz & Hafif & 320750 \\
\hline 45 & Lezyon/yüz & Orta & 291116 \\
\hline 46 & Lezyon/boyun & Orta & 2460000 \\
\hline 47 & Lezyon yok/boyun & Orta & 165634 \\
\hline
\end{tabular}

li yöntemler geliştirilmiştir., ${ }^{89}$ Bu yöntemlerden en etkili olanı yapışkan film kullanarak deri yüzeyinden örnek alınması ve filmin yüzeyine yapışan Malassezia hücrelerinin kantitatif olarak sayılmasıdır. ${ }^{10}$ AD'li hastaların deri örneklerinde Malassezia kolonizasyonunun kantitatif olarak gösterilmesi için, örnek alınmasından başlayarak, DNA eldesi, DNA çoğaltılma basamağı olmak üzere bütün aşamalarda kalite kontrolüne dikkat edilmiştir. Örnek alma aşamasında yapışkan film yönteminin seçilmesinin nedeni, filmin deri yüzeyine bütünüyle yapışması ve kazıntı örneklerine göre daha yaygın örnek alınmasına imkan vermesindendir. ${ }^{6}$

Çalışmamızda AD ve sağlıklı kişilerin deri örneklerinde Malassezia cinsine ait DNA araştırılmıştır. AD'in klinik seyri ile fungal yük arasında bir ilişki gösterilmemiştir. Bu çalışmanın başlangıç hipotezi "AD'li hastalarda Malassezia kolonizasyonu daha fazladır" olmasına rağmen, gruplar arasında fungal yük açısından bir fark gösterilememiştir. Benzer çalışmalarda, AD'li hastaların Malassezia ile kolonize olma oranlarının sağlıklı kişilerden ve seboreik dermatitli olgulardan daha yüksek olduğu bildirilmiştir. ${ }^{11-13} A D^{\prime} l i$ hastaların derisi nötral $\mathrm{pH}^{\prime}$ da olduğu için Malassezia gibi mayaların yerleşmesini kolaylaştırmaktadır. ${ }^{14}$

Yüz ve boyun bölgelerinde AD bulunan hastaların, lezyon bölgelerinde Malassezia kolonizasyonunun fazla olduğu, ve bu kişilerin Malassezia için özgül IgE antikorları taşıdıkları gösterilmiştir. AD hastalarında diğer mantarlardan çok daha fazla Malassezia için gelişmiş Tip 1 aşırı duyarlık tablosu bulunmaktadır.,9 AD patogenezi karmaşık bağışıklık mekanizmalarını içermekte olup, tam olarak anlaşılabilmiş değildir.

Sugita ve ark. AD'li hastalarda kolonize olduğu gösterilen yeni bir Malassezia türünü isimlendirmişlerdir. ${ }^{15-17} \mathrm{Bu}$ araştırıcı grubunun, derinin mikrobiyal bileşenleri ile ilgili çok sayıda yayınlanmış çalışmaları bulunmaktadır. ${ }^{18}$ Sugita ve ark. AD grubunda 9 ayrı Malassezia türü ile kolonizasyonun söz konusu olduğunu, bazı olguların 3-4 ayrı tür ile kolonize olduklarını göstermişlerdir. Malassezia hücreleri erkeklerde 16-18 yaşına kadar, kızlarda 10-12 yaşına kadar artmakta, sonra giderek azalmaktadır. Japonya'da yapılan bu çalışmalarda AD olgularında Malassezia yükünün sağlıklılardan çok fazla olduğu gösterilmiştir. ${ }^{10-13}$ Fakat bu bulgular bizim çalışmamıza dahil ettiğimiz Türk hastalar ile doğrulanmamıştır. Bu birbirinden farklı iki sonuç derideki Malassezia kolonizasyonunun coğrafik ve etnik faktörlerden etkilenebileceğini göstermektedir. Ayrıca kullanılan yönteme bağlı farklılıkların da sonuçları etkileyebileceği bilinmelidir. Malassezia cinsi mayaların deri hastalıklarının patogenezindeki rollerinin tam olarak anlaşılabilmesi için, farklı etnik gruplardan seçilmiş hastaların yer alığı, standardize edilmiş kantitatif yöntemlerin kullanıldığı geniş çalışmalara ihtiyaç vardır. Deri hastalıklarının patogenezinde rol alan mikroorganzimaların incelenmesi bu hastalıkların tedavisinde yeni seçeneklerin oluşturulmasında yararlı olacaktır.

\section{Kaynaklar}

1. Faergemann J: Atopic dermatitis and fungi. Clin Microbiol Rev 2002;15:545-63.

2. Gupta AK, Batra R, Bluhm R, Boekhout T, Dawson TL Jr: Skin diseases associated with Malassezia species. J Am Acad Dermatol 2004;51:785-98.

3. Ashbee HR: Update on the genus Malassezia. Med Mycol 2007;45:287-303.

4. Ertam I, Aytimur D: Malassezia spp. ve dermatolojideki yeri. Türkderm 2006;40:7-10.

5. Hanifin JM, Rajka G: Diagnostic features of atopic dermatitis. Acta Derm Venereol 1980;92:4-47.

6. Sugita T, Suto H, Unno T, Tsuboi R, Ogawa H, Shinoda T, et al: Molecular analysis of Malassezia microflora on the skin of atopic dermatitis patients and healthy subjects. J Clin Microbiol 2001;39:3486-90. 
7. Sugita T, Tajima M, Tsubuku H, Tsuboi R, Nishikawa A: Quantitative analysis of cutaneous Malassezia in atopic dermatitis patients using realtime PCR. Microbiol Immunol 2006;50:549-52.

8. Bayrou O, Pecquet C, Flahault A, Artigou C, Abuaf N, Leynadier F: Head and neck atopic dermatitis and Malassezia furfur-specific IgE antibodies. Dermatology 2005;211:107-13.

9. Kato $H$, Sugita $T$, Ishibashi $Y$, Nishikawa A: Detection and quantification of specific IgE antibodies against eight Malassezia species in sera of patients with atopic dermatitis by using an enzyme-linked immunosorbent assay. Microbiol Immunol 2006;50:851-6.

10. Kaga M, Sugita T, Nishikawa A, Wada Y, Hiruma M, Ikeda S: Molecular analysis of the cutaneous Malassezia microbiota from the skin of patients with atopic dermatitis of different severities. Mycoses (Baskıda).

11. Takahata Y, Sugita T, Kato H, Nishikawa A, Hiruma M, Muto M: Cutaneous Malassezia flora in atopic dermatitis differs between adults and children. Br J Dermatol 2007;157:1178-82.

12. Sugita T, Suzuki M, Goto S, Nishikawa A, Hiruma M, Yamazaki T, et al: Quantitative analysis of the cutaneous Malassezia microbiota in 770 healthy Japanese by age and gender using a real-time PCR assay. Med Mycol 2010;48:229-33
13. Sugita $T$, Tajima $M$, Amaya $M$, Tsuboi $R$, Nishikawa $A$ : Genotype analysis of Malassezia restricta as the major cutaneous flora in patients with atopic dermatitis and healthy subjects. Microbiol Immunol 2004;48:755-9.

14. Howell MD: The role of human beta defensins and cathelicidins in atopic dermatitis. Curr Opin Allergy Clin Immunol 2007;7:413-7.

15. Sugita T, Tajima M, Takashima M, Amaya M, Saito M, Tsuboi R: New yeast species, Malassezia yamatoensis, isolated from a patient with seborrheic dermatitis, and its distribution in patients and healty subjects. Microbiol Immunol 2004;48:579-83.

16. Sugita T, Takashima M, Kodama M, Tsuboi R, Nishikawa A: Description of a new yeast species, Malassezia japonica, and its detection in patients with atopic dermatitis and healthy subjects. J Clin Microbiol 2003;41:4695-9.

17. Sugita T, Takashima M, Shinoda T, Suto H, Unno T, Tsuboi R et al: New yeast species, Malassezia dermatis, isolated from patients with atopic dermatitis. J Clin Microbiol 2003;41:1363-7.

18 Sugita T, Kodama M, Saito M, Ito T, Kato $Y$, Tsuboi $R$ et al: Sequence diversity of the intergenic spacer region of the rRNA gene of Malassezia globosa colonizing the skin of patients with atopic dermatitis and healthy individuals. J Clin Microbiol 2003;41:3022-7. 